\title{
PROGRAM PENINGKATAN KEAHLIAN APLIKASI MICROSOFT WORD 2013 GURU-GURU PENGAJAR DI PASRAMAN "WIDYA DHARMA" CIMAHI
}

\author{
I Made Yadi Dharma ${ }^{1}$, Marwanto Rahmatuloh ${ }^{2}$ \\ Politeknik Pos Indonesia. Email: imadeyadi@poltekpos.ac.id \\ Politeknik Pos Indonesia. Email:mrahmatuloh@ poltekpos.ac.id
}

\begin{abstract}
PASRAMAN is a collection of Hindu religious teachers appointed by the Department of Education to teach Hinduism. The students come from schools from the City of Cimahi and West Bandung District.

PASRAMAN was appointed as a representative of Hinduism teachers because in general, the schools did not provide special teachers for Hindu religious studies. This is because the students are few, sometimes one school is only one person. Therefore, specifically for Hindu religious subjects submitted to PASRAMAN from all cities in Cimahi and West Bandung Regency.

The training that will be given to the teachers of Hindu Religion Pasraman is the Microsoft Word 2013 Training, where the Hinduism teachers are based on the analysis of researchers, but also master the Computer Applications. This research will be conducted in Pasraman itself. This training will be linked to the interests of data processing of teachers who are often assisted by researchers in operating computer applications.
\end{abstract}

Keywords: Pasraman, Teacher, Cimahi, Training.

\begin{abstract}
Abstrak
PASRAMAN adalah kumpulan guru-guru Agama Hindu yang di tunjuk Dinas Pendidikan untuk mengajar agama Hindu. Siswa-siswanya berasal dari sekolah-sekolah yang berasal dari Kota Cimahi dan Kabupaten Bandung Barat.

Ditunjuknya PASRAMAN sebagai perwakilan guru-guru Agama Hindu dikarenakan pada umumnya sekolah-sekolah tidak menyediakan guru khusus untuk pelajaran agama Hindu. Hal ini dikarenakan muridnya yang sedikit, terkadang satu sekolah hanya 1 orang. Maka dari itu khusus untuk mata pelajaran agama Hindu diserahkan ke PASRAMAN dari semua kota yang ada di Cimahi dan Kabupaten Bandung Barat.

Pelatihan yang akan diberikan kepada guru-guru Agama Hindu Pasraman adalah Pelatihan Microsoft Word 2013, dimana guru-guru Agama Hindu tersebut berdasarkan analisis peneliti, balum menguasai Aplikasi Komputer. Penelitian ini akan dilaksanakan di Pasraman sendiri. Pelatihan ini akan di kaitkan dengan kepentingan pengolahan data guru-guru yang sering dibantu peneliti dalam mengoperasikan aplikasi komputer.
\end{abstract}

Kata Kunci : Pasraman, Guru, Cimahi, Pelatihan. 


\section{PENDAHULUAN}

Pasraman adalah sebuah asrama yang dikhususkan untuk masyarakat yang beragama Hindu. Siswa Pasraman berasal dari berbagai sekolah mulai dari Sekolah Dasar (SD), Sekolah Lanjutan Pertama (SLTP) dan Sekolah Lanjutan Atas (SLTA) yang ada di kota Cimahi dan Kabupaten Bandung Barat. Aktivitas Pasraman adalah sebagai penyelenggara pelajaran Agama Hindu yang resmi di tunjuk dari beberapa sekolah yang ada di Cimahi, Bandung dan Kabupaten Bandung Barat.

Dari hasil analisis peneliti dilapangan, para guru-guru di Pasraman tidak menguasai Aplikasi Komputer dikarenakan background mereka tidak semua yang berlatarbelakang pendidikan Teknologi Informasi, sehingga dalam pembuatan tabel, mereka masih menggunakan format tabel dan surat menyurat masih menggunakan dengan cara standar dan kurang tertata dengan baik.

Berdasarkan kondisi tersebut sehingga peneliti memberikan pelatihan yang resmi dan terstruktur melalui LPPM Politeknik Pos Indonesia. Diharapkan setelah pelatihan Microsoft Word ini, para guru-guru Pasraman dapat lebih semangat dalam menggunakan Aplikasi Microsft Word dan aplikasi-aplikasi lainnya.

\section{METODE PENELITIAN}

Tahapan dari pelaksanaan pelatihan Program Peningkatan Keahlian Aplikasi Microsoft Word 2013 Guru-guru Pengajar di PASRAMAN "WIDYA DHARMA” Cimahi menggunakan Metode Studi Kasus, dimana peneliti sudah berinteraksi langsung dengan guruguru Agama Hindu di Pasraman.

\subsection{Persiapan}

Pada tahap persiapan, tim peneliti melakukan observasi ke lokasi dan menganalisa untuk mengetahui kebutuhan- kebutuhan apa saja yang perlukan. Hasil analisa ini dijadikan bahan untuk pembuatan materi pelatihan

\subsection{Proses Pelatihan}

Kegiatan pelatihan dilakukan di salah satu ruangan milik Pasraman.Peserta menggunakan laptop masing-masing. Materi yang diberikan adalah Microsoft Word 2013. Untuk mempermudah proses pelatihan, semua laptop harus terinstal microsoft office.

Materi yang diberikan mulai dari pengelolaan manajemen file, seperti windows explorer dan cara-cara penggunaannya. Kemudian dilanjutkan dengan materi pokok yaitu latihan menggunakan microsoft word 2013. Ada beberapa guru yang memang tidak pernah samasekali menggunakan komputer, sehingga peneliti sedidkit mengalami hambatan dalam pelatihan. Materi pelatihan hanya mencakup sedikit materi word secara umum dan lainnya adalah materi yang berhubungan dengan pekerjaan guru-guru Pasraman, seperti pembuatan tabel untuk daftar siswa Pasraman, pembuatan laporan, seperti penggunaan paragraph, page layout, page setup, dan lain-lain.

\subsection{Penutupan}

Acara terakhir adalah acara penutupan. Pada acara penutupan ini, peserta menyampaikan beberapa hal :

- Peserta memberikan masukan kepada peneliti agar pelatihan seperti ini diadakan 
kembali di Pasraman dengan materi yang berbeda, seperti Microsodt Excel, Powerpoint dan lain-lainnya.

- Peserta dan pimpinan Asrama Pasraman mengucapkan terimakasih atas bantuan pelatihan yang diberikan oleh LPPM Politeknik Pos Indonesia kepada Pasraman, dan berharap kerjasama ini tetap dapat berlanjut pada waktu yang akan datang.

\section{HASIL DAN LUARAN YANG DICAPAI}

\subsection{Hasil Pelatihan}

Hasil dari pelatihan ini berupa panduan penggunaan microsoft word beserta latihanlatihan yang dapat membantu pihak Pasraman dalam melaksanakan tugas sehari-hari. Paduan penggunaan micrososft word ini di perbanyak dan diberikan kepada setiap peserta.

\subsection{Luaran yang di Capai}

Luaran yang dicapai dari pelatihan ini adalah sebuah draft karya ilmiah yang akan diterbitkan ke majalah Competitive LPPM Politeknik Pos Indonesia.

\section{KESIMPULAN}

Setelah semua proses kegiatan Pelatihan Program Peningkatan Keahlian Aplikasi Microsoft Word 2013 Guru-guru Pengajar di PASRAMAN "WIDYA DHARMA” CIMAHI selesai dilaksanakan, maka dapat di simpulkan sebagai berikut :

1. Kegiatan Pelatihan Program Peningkatan Keahlian Aplikasi Microsoft Word 2013 Guruguru Pengajar di PASRAMAN "WIDYA DHARMA" sangat bermanfaat untuk menambah ilmu pengetahuan di bidang komputer.

2. Peserta sudah dapat menggunakan microsoft word dengan baik, walaupun ada beberapa peserta yang masih perlu penambahan pelatihan lagi.

\section{REFERENSI}

1. Hernawan Sulistyanto. 2017. Pakom Pelatihan Pengoperasian komputer bagi perangkat desa di kecamatan gondangrejo Kabupaten Karanganyar. WARTA LPM, Vol. 20, No. 2.

2. Suripto, dkk. 2015. Penggunaan Teknologi Informasi dan Dampaknya dalam Dunia Pendidikan.

3. Auliya Rahman, dkk. Pelatihan Komputer Program Microsoft Excel 2013 pada SMAN 12 Banjarmasin. Al-Ikhlas Volume 1 Nomor 1, Oktober 2015.

4. Sormunen, J. and Parks, D. (1988), "Chief executive scanning, environmentalcharacteristics, and company performance: an empirical study", Strategic ManagementJournal, Vol. 9 No. 2, pp. 123-39. 